\title{
Urinary catheterization in gynecological surgery: When should it be removed?
}

\author{
Adly N.A. Fattah, Budi I. Santoso
}

Department of Obstetric and Gynecology, Faculty of Medicine, Universitas Indonesia, Cipto Mangunkusumo Hospital, Jakarta, Indonesia

\begin{abstract}
Abstrak
Latar belakang: Tujuan dari studi ini adalah menentukan waktu yang paling tepat untuk melepaskan kateter urin pascaoperasi ginekologi.

Metode: Laporan berbasis bukti ini disusun dari telaah kritis artikel uji klinis. Laporan ini bertujuan menjawab pertanyaan klinis kami, yaitu apakah pelepasan kateter urin 24 jam pasca-operasi lebih baik dibandingkan pelepasan pada durasi lainnya dalam hal mencegah terjadinya retensio urin pasca-operasi dan infeksi saluran kemih? Pencarian literatur dilakukan pada situs Cochrane Library ${ }^{\circledR}$ dan PubMed ${ }^{\mathbb{B}}$ dengan kata kunci "postoperative urinary retention", "postoperative catheterization" dan "urinary retention AND catheterization". Pencarian untuk artikel uji klinis lain juga dilakukan secara manual pada daftar pustaka artikel yang ditemukan.
\end{abstract}

Hasil: Telaah kritis dilakukan terhadap 6 uji klinis terandomisasi yang melibatkan 846 perempuan yang menjalani histerektomi dan operasi prolaps organ panggul (POP) dilakukan untuk mencari tingkat re-kateterisasi dan infeksi saluran kemih (ISK). Subjek pada kelompok "pelepasan lebih awal" memiliki risiko 3 sampai 4 kali lebih tinggi mengalami re-kateterisasi (OR =3,10-4,00) dibandingkan dengan kelompok "pelepasan lebih akhir". Sementara itu, kelompok yang dilepaskan pada hari ke-5 memiliki risiko 14 kali lebih tinggi mengalami ISK dibandingkan dengan kelompok yang dilepaskan segera $(O R=14,786,95 \%$ CI 3,187-68,595).

Kesimpulan: Kebijakan kateterisasi 24 jam pasca histerektomi dan operasi POP masih merupakan pilihan yang tepat, walaupun berhubungan dengan peningkatan risiko re-kateterisasi. Pelepasan kateter sebelum 24 jam (6 dan 12 jam) dapat dipertimbangkan sebagai salah satu intervensi pada uji klinis di kemudian hari, sehingga dapat ditemukan durasi terbaik yang menghasilkan insiden ISK dan retensio urin pasca-operasi yang paling rendah. (Med J Indones. 2013;22:183-8. doi: 10.13181/mji.v22i3.589)

\begin{abstract}
Background: The aim of this study was to determine the most appropriate time for urinary catheter removal following a gynecological surgery.

Methods: Critical appraisal of clinical trial articles were conducted. It was aimed to answer our clinical question whether 24-hour postoperative urinary catheter removal is superior compared to other durations in avoiding postoperative urinary retention (PUR) and urinary tract infection (UTI). The search was conducted on the Cochrane Library ${ }^{\circledR}$ and PubMed $^{\circledR}$ using keywords "postoperative urinary retention", "postoperative catheterization" and "urinary retention AND catheterization". Reference lists of relevant articles were searched for other possibly relevant trials.

Results: Seven articles were available as full text, then appraisals of six prospective RCTs involving 846 women underwent hysterectomy and vaginal prolapse surgery were performed finding at the re-catheterization and UTI rate. Subjects in earlier-removal groups were 3 to 4 times more likely to have re-catheterization $(\mathrm{OR}=3.10-4.0)$ compared to later-removal groups, while they who have it removed on $5^{\text {th }}$ day were 14 times more likely to develop UTI compared with immediate group $(\mathrm{OR}=14.786,95 \%$ CI 3.187- 68.595).

Conclusion: The 24-hour catheterization policy in hysterectomy and vaginal prolapse surgery remains most appropriate although associated with an increased risk of re-catheterization. The removal of catheter before 24 hours (6 or 12 hours) could be considered to be used as one of interventions in further RCT(s) to find out the best duration which would result in lowest incidence in both of UTI and PUR. (Med J Indones. 2013;22:183-8. doi: 10.13181/mji.v22i3.589)
\end{abstract}

Keywords: Catheter, hysterectomy, prolapse, urinary tract infection

Urinary catheterization after gynecology surgery is commonly performed to evaluate urine output and avoid urinary retention. However, its implementation was relatively custom-based, hospital policy-based, and personal preference-dependent, therefore the duration varies markedly. ${ }^{1-3}$ The catheterization duration varies depending on hospital policy, institutional habit and personal preference. Adverse event such as postoperative urinary retention
(PUR) occurs approximately in $0 \%$ to $70 \%$ patients depending on the type of the surgery. ${ }^{4,5}$ Undetectable urinary retention might lead to over-distended bladder, detrusor injury, increased risk of infection, and long term voiding dysfunction. ${ }^{6-8}$ Moreover, bladder overfilling predicted to have a negative influence on surgical outcome after prolpase surgery. ${ }^{9}$ Consequently, the length of stay, costs, and morbidity could be increased due to PUR. ${ }^{7,10,11}$ 
Postoperative catheterization duration policy should be based on evidence obtained from randomized controlled trials (RCTs). The time of urinary catheter removal after a number of gynecology surgery differs among several authors; urinary catheters removed on day-5, day-4, day-2, day-1, 3 hours, and immediately after prolapse surgery. ${ }^{9,12,13}$ Patients underwent hysterectomy would have their urinary catheters removed on 24 hours, 12 hours, 6 hours, or immediately following surgery. ${ }^{14}$

Although the result of study regarding the catheterization duration remains controversial, Cochrane Review had stated that fewer Urinary Trac Infection (UTI) reported when catheters were removed earlier in seven out of 11 trials. ${ }^{15}$ Catheterassociated UTI is an important factor to be considered in determining the duration because it accounts for $80 \%$ of hospital-acquired infections. ${ }^{16,17}$

In Cipto Mangunkusumo Hospital, Jakarta the duration of catheterization is 24 hour for uncomplicated hysterectomy. For several cases, the duration was decided by the surgeon based on clinical monitoring of the patients and other considerable factors. The objective of this study is to determine the most appropriate time to remove urinary catheter after gynecologic surgery considering the urinary tract infection risk and re-catheterization. Consequently, the postoperative catheter duration policy in the hospital could be based on the best evidence.

\section{Clinical question}

Does 24 hour postoperative urinary catheters removal superior compared to other duration (day-5, day-4, day-2, 12 hours, 6 hours, 3 hours, and immediately after surgery) to prevent PUR and UTI?

\section{METHODS}

\section{Search strategy}

The search was conducted on January $18^{\text {th }} 2013$ on the Cochrane Library ${ }^{\circledR}$ and PubMed ${ }^{\circledR}$ with the keywords of "postoperative urinary retention", "postoperative catheterization", and "urinary retention AND catheterization". Search focused on articles in clinical trial design. Reference lists of relevant articles were searched for other possibly relevant trials. (see figure 1 for details).

\section{Selection}

After obtaining a result, a first selection was done by screening the study titles and abstracts. (See appendix
Figure 1 for an overview of the selection of articles). Seven articles were available as full text, and six of them included in our analysis.

\section{Critical appraisal}

Appraisal of six prospective RCTs involving 846 women undergoing gynecological surgery were conducted finding at the re-catheterization rate and UTI. The type of surgery and interventions are different among 6 studies, however it still comparable when we used RCT appraisal questions developed by Makela et al. ${ }^{18,19}$

\section{Operational definitions}

\section{Urinary retention}

There are several definitions of urinary retention used in this study based on different authors. Hakvoort dan Weemhoff defined urinary retention as post-voiding residual volume of $200 \mathrm{~mL}$ or more measured by ultrasound scanner within 8 hours after removal of the catheter.,12 Kamilya and Glavind defined it as urinary bladder volume exceeded $150 \mathrm{~mL}$ and 300 $\mathrm{mL}$ respectively. ${ }^{1,13}$ Patients who could not empty their bladder 6 hours after catheter removal ${ }^{14,16}$ or when there was no urge within 8 hours after the catheter removal $^{1}$ are also categorized as having urinary retention. Glavind state that they who could not void spontaneously 4 hour after catheter removal is already defined as urinary retention. ${ }^{13}$ In addition, Hakvoort used the term of urinary retention to describe subjects who had another transurethral catheter inserted for a period of three days (re-catheterization). ${ }^{9}$

\section{Urinary tract infection and urine cultures}

In most of articles, UTI defined as the presence of more than $10^{5}$ colony forming units $/ \mathrm{mL}$ in the culture. ${ }^{9,12-14}$. However some authors added a number of clinical findings to complete this definition. Kamilya defined UTI as a positive urine culture of more than $10^{5} \mathrm{CFU} /$ $\mathrm{mL}$, plus one of the following: dysuria, fever more than $38.5^{\circ} \mathrm{C}$ or rigors. ${ }^{1}$ While Alessandri defined it as a positive urine culture of more than $10^{5} \mathrm{CFU} / \mathrm{mL}$, accompanied by at least one of the following symptoms: dysuria, increased frequency of urination, urinary urgency, suprapubic pain, burning on micturition, or onset or aggravation of urinary incontinence. ${ }^{16}$

In all studies, two or three urine cultures were taken from each participant at these periods: (1) preoperative urine culture (before admission ${ }^{1}$ or prior to surgery or at the start of the operation $\left.{ }^{9,12-14}\right)$, (2) 


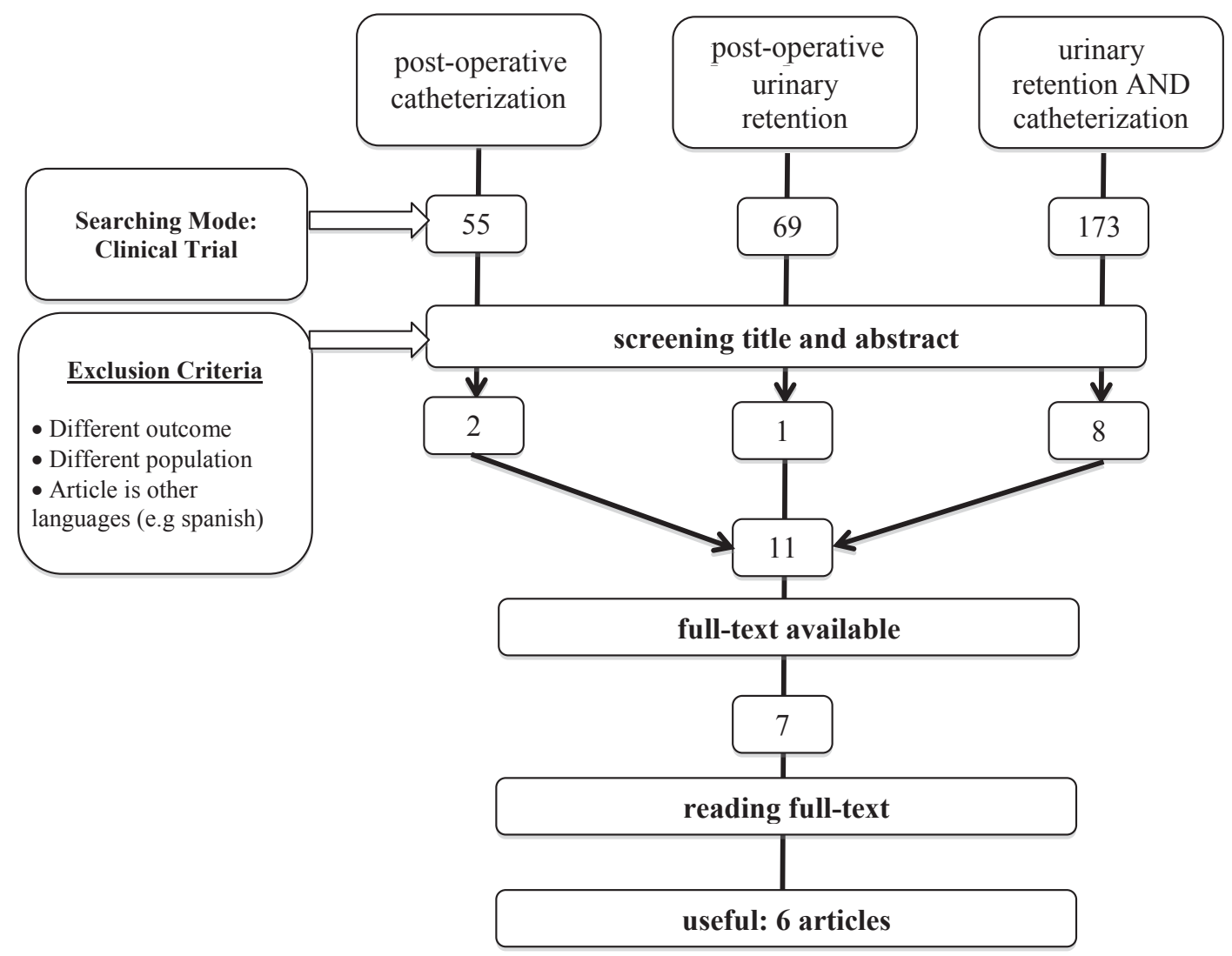

Figure 1. Searching flow

on the day of catheter removal (before or at time of catheter removal $\left.{ }^{1,9,14}\right)$, (3) the day after the operation and 14 days after the operation, ${ }^{13}$ or (4) when there is a complaint of symptoms of UTI after catheter removal. ${ }^{14}$

\section{RESULT}

The average rate of re-catheterization after vaginal prolapse surgery from 4 RCTs in this study was $15 \%$, while the UTI was $22.7 \%$. The incidence of recatheterization and UTI after hysterectomy gathered from 2 RCTs were respectively $7.9 \%$ and $14.6 \%$. Two out of four RCTs regarding catheterization after prolapse surgery resulted in statistically significant higher incidence of re-catheterization in earlier removal groups ( $1^{\text {st }}$ and $2^{\text {nd }}$ day). One RCT shows an extremely significant risk of UTI in the laterremoval group.

In the study of 100 women underwent anterior colporrhaphy only of combined with posterior colporrhaphy and/or vaginal hysterectomy, it is found that UTI rate was higher in the 5th day-catheter removal group $(40 \%)$ compared with $4 \%$ in group who have their catheter removed at the morning after surgery
$(\mathrm{OR}=14.786,95 \%$ CI $3.187-68.595) .{ }^{9}$ In the second study, subjects who have the catheter removed in the operating room immediately were have significantly higher re-catheterization rate compared to them who have it removed on 1 st day after the operation $(20 \%$ vs $0 \%, \mathrm{p}=0.011) .{ }^{14}$ The constant result was revealed by Kamilya, et al in their RCT involving 200 women underwent vaginal prolapse surgery. Participants in 1st day catheter removal group were three times more likely to have re-catheterization compared with them who were allocated in 4th day catheter removal group $\left(\mathrm{OR}=3.10,95 \%\right.$ CI 1.301-7.399). ${ }^{1}$ Weemhoff et al. supported the result by concluding that 2 days group was 4 times more likely to have re-catheterization compared to 5 days group $(\mathrm{OR}=4.0,95 \% \mathrm{CI} 1.9-8.3){ }^{12}$

Alessandri, et al conducted a different RCT by allocating 96 women who underwent various type of hysterectomy into three groups. They who had the catheter removed immediately after the operation have significantly higher re-catheterization rate compared to 6 hour and 12 hour group ( $18.8 \%$ vs $0 \%$ vs $0 \%) .{ }^{16}$ A study done by Glavind, et al resulted in higher incidence of re-catheterization rate among women who had the catheter removed at 3 hours compared to 24 hours postoperative group ( $4.5 \%$ vs $1.47 \%){ }^{13}$ 
Table 1. Critical appraisal summary based on 6 published RCT

\begin{tabular}{|c|c|c|c|c|c|c|c|c|c|c|c|c|c|}
\hline \multirow{2}{*}{ No } & \multirow{2}{*}{ Study } & \multirow{2}{*}{$\begin{array}{l}\text { Type of } \\
\text { surgery }\end{array}$} & \multirow{2}{*}{ Sample } & \multirow{2}{*}{$\begin{array}{l}\text { Cath. } \\
\text { Removal }\end{array}$} & \multicolumn{5}{|c|}{ Validity } & \multicolumn{2}{|c|}{ Result } & \multirow{2}{*}{$\frac{\text { Applicability }}{8}$} & \multirow{2}{*}{$\begin{array}{l}\text { Total } \\
\text { Score }\end{array}$} \\
\hline & & & & & 1 & 2 & 3 & 4 & 5 & 6 & 7 & & \\
\hline 1. & $\begin{array}{l}\text { Hakvoort, } \\
\text { et al (2004) }\end{array}$ & $\begin{array}{l}\text { Vaginal } \\
\text { prolapse }\end{array}$ & 100 & $\begin{array}{l}\text { Day-5 vs } \\
\text { Morning } \\
\text { after surgery }\end{array}$ & + & $?++$ & $+?$ & -- & ++ & + & ++ & ++ & $11 / 16$ \\
\hline 2. & $\begin{array}{l}\text { Chai, et al } \\
\text { (2011) }\end{array}$ & $\begin{array}{l}\text { Total } \\
\text { abdominal } \\
\text { hysterectomy }\end{array}$ & 70 & $\begin{array}{l}\text { Immediately } \\
\text { after vs } \\
\text { day } 1\end{array}$ & + & +++ & ++ & +++ & ++ & + & +- & ++ & $15 / 16$ \\
\hline 3. & $\begin{array}{l}\text { Kamilya, et } \\
\text { al (2010) }\end{array}$ & $\begin{array}{l}\text { Vaginal } \\
\text { prolapse }\end{array}$ & 200 & $\begin{array}{l}\text { Day I vs } \\
\text { day } 4\end{array}$ & + & +++ & ++ & -- & ++ & + & ++ & ++ & $13 / 16$ \\
\hline 4. & $\begin{array}{l}\text { Alessandri, } \\
\text { et al (2006) }\end{array}$ & $\begin{array}{l}\text { Various } \\
\text { type of } \\
\text { hysterectomy }\end{array}$ & 96 & $\begin{array}{l}\text { Immediately } \\
\text { vs } 6 \text { hour vs } \\
12 \text { hour }\end{array}$ & + & +++ & ++ & -- & ++ & + & +- & ++ & $12 / 16$ \\
\hline 5. & $\begin{array}{l}\text { Weemhoff, } \\
\text { et al (2011) }\end{array}$ & $\begin{array}{l}\text { Anterior } \\
\text { Colporrhaphy }\end{array}$ & 246 & $\begin{array}{l}\text { Day-2 vs } \\
\text { Day-5 }\end{array}$ & + & +++ & $+?$ & --+ & ++ & + & +- & ++ & $12 / 16$ \\
\hline 6. & $\begin{array}{l}\text { Glavind, et } \\
\text { al (2007) }\end{array}$ & $\begin{array}{l}\text { Vaginal } \\
\text { prolapse } \\
\text { surgery }\end{array}$ & 134 & $\begin{array}{l}3 \text { hour vs } 24 \\
\text { hour }\end{array}$ & + & $?+?$ & $+?$ & --- & -+ & + & - - & ++ & $7 / 16$ \\
\hline
\end{tabular}

1 research question, 2 randomization, 3 blinding, 4 follow-up, 5 intervention \& co-intervention, 6 selection of outcomes, 7 effect size, 8 using result in your own setting, +, adequate; -, inadequate; ?, unknown, no information given. Every item was scored based on RCT appraisal questions developed by Makela, et al ${ }^{18}$

Table 2. Re-catheterization rate and urinary tract infections in vaginal prolapse surgery from 4 authors

\begin{tabular}{lcll}
\hline \multicolumn{1}{c}{ Study } & $\begin{array}{r}\text { Time of } \\
\text { removal }\end{array}$ & \multicolumn{1}{c}{$\begin{array}{c}\text { Re catheterization } \\
\mathrm{n}(\%)\end{array}$} & $\begin{array}{c}\text { UTI } \\
\mathrm{n}(\%)\end{array}$ \\
\hline Glavind & 3 hours & $3 / 66(4.5 \%)$ & $8 / 56(14.3 \%)$ \\
Hakvoort, Kamilya, Glavind* & day 1 & $19 / 48(40 \%)$, & $2 / 48(4 \%)$, \\
& & $21 / 98(21.4 \%)$, & $5 / 98(5.1 \%)$, \\
& & $1 / 68(1.47 \%)$ & $12 / 55(21.8 \%)$ \\
Weemhoff & day 2 & $35 / 123(28 \%)$ & $22 / 101(22 \%)$ \\
Kamilya & day 4 & $8 / 99(8.1 \%)$ & $34 / 99(34.3 \%)$ \\
Hakvoort, Weemhoff* & day 5 & $4 / 46(9 \%)$, & $18 / 46(40 \%)$, \\
& & $11 / 122(9 \%)$ & $35 / 95(37 \%)$ \\
Total & & $102 / 670(15 \%)$ & $136 / 598(22.7 \%)$ \\
\end{tabular}

*In order to simplify the analysis, incidence of re-catheterization and UTI for vaginal prolapse surgery in day 1 removal group, were added together from 3 studies and for day 5 group from 2 studies (Figure 2, right)

\section{DISCUSSION}

\section{Choosing the best study}

Study conducted by Chai, et al has the higher appraisal score compared to Alessandri's. It is mainly due to the zero lost to follow-up and discontinued intervention number. Both of them did not mention the use of intention-to-treat analysis, whereas this analysis actually may assist us to reflect the real condition in daily practice when complications and deaths are possibly occurred. Among 4 studies on prolapse surgery, study conducted by Kamilya, et al has the highest total score. It is mostly due to the clearly-stated allocation and randomization at the research methods. In contrary, Hakvoort and Glavind did not explain their group randomization methods. 

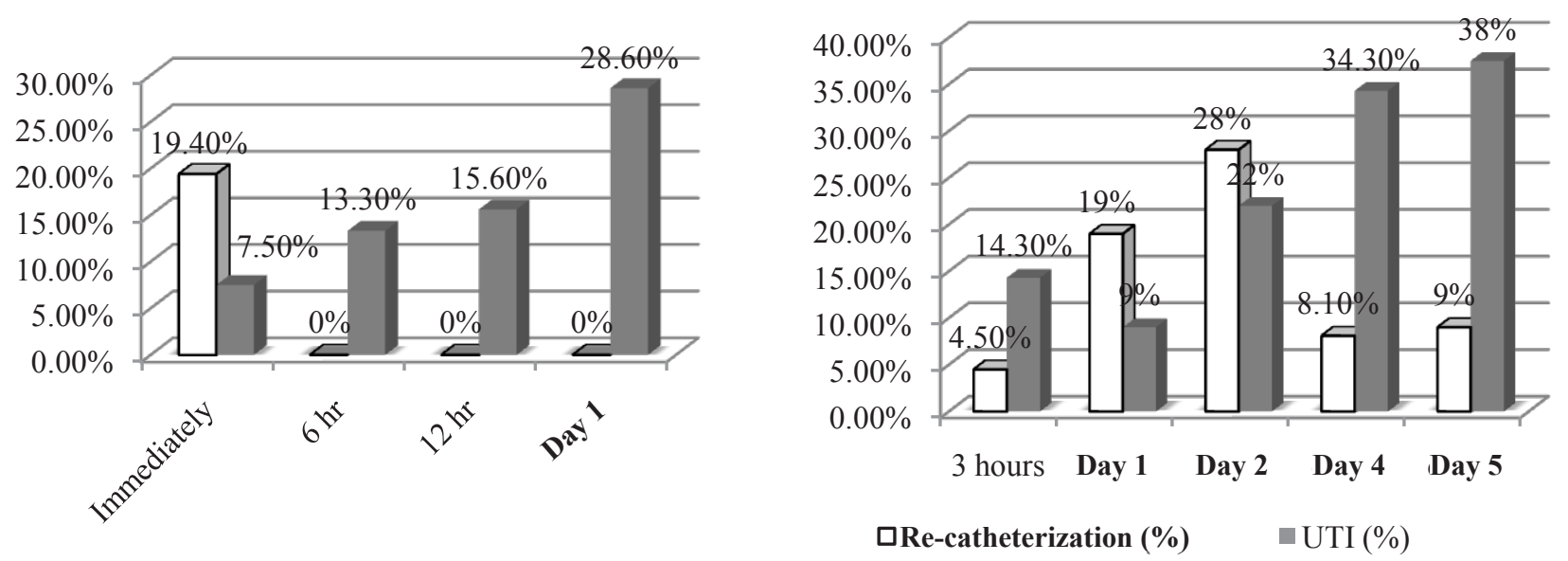

Figure 2. Re-catheterization and UTI rate in hysterectomy (Left $)^{1,2}$ and prolapse surgery (Right $)^{3-6}$

\section{Re-catheterization rate and UTI}

In these studies the re-catheterization rates are ranging from $0 \%$ to $28 \%$. This result are in accordance with previous studies, which the incidence of PUR reported range from $0 \%$ to $63 \%{ }^{2,7}$ This wide range of incidence could possibly affected by the definitions used, catheterization timing and duration policies, and complications during surgery.

Figure 2 gives a brief overview about the proportion of UTI and re-catheterization rate from several catheterization groups. The re-catheterization rate in prolapse surgery was highest when the catheter removed on the second day. Despite of the subtype of surgery, this result confirms findings by Hakvoort, et al in which $40 \%$ of patients had retention in day 1 protocol group. ${ }^{9}$ In addition, Sekhavat demonstrated significantly less pain and voiding disturbances in early catheter-removal group compared to control group (catheters removed at least 24 hours after operation).$^{20}$

In hysterectomy procedures, 6 hours group seems to have the lowest both of re-catheterization and UTI rate compared to other groups. ${ }^{16}$ This finding supports the study conducted by Dunn et al which stated early removal catheters was not associated with UTI, recatheterization, and increased rate of febrile events. This study tend to prefer early removal of catheters than 24 hour catheterization with the consideration of significantly lesser pain assessment in the early removal group. ${ }^{21}$ Since the result from several trials remains inconstant, Cochrane statement regarding the positive association between shorter postoperative duration with fewer UTI can be counted as the primary consideration to create the policy in the hospital. ${ }^{22}$
In conclusion, 24 hour catheterization policy in hysterectomy and vaginal prolapse surgery remains most appropriate although associated with an increased risk of re-catheterization. The removal of catheter before 24 hour (6 or 12 hour) could be considered to be used as one of interventions in further RCT(s) to find out the best duration which would result in lowest incidence in both of UTI and PUR.

\section{REFERENCES}

1. Kamilya G, Seal SL, Mukherji J, Bhattacharyya SK, Hazra A. A randomized controlled trial comparing short versus long-term catheterization after uncomplicated vaginal prolapse surgery. J Obstet Gynaecol Res. 2010;36(1):154-8.

2. Schiøtz HA, Tanbo TG. Postoperative voiding, bacteriuria and urinary tract infection with Foley catheterization after gynecological surgery. Acta Obstet Gynecol Scand. 2006;85(4):476-81.

3. Wyman A. What time of day should a urethral catheter be removed? J R Soc Med. 1987;80(12):755-6.

4. Weinberger MW, Ostergard DR. Postoperative catheterization, urinary retention, and permanent voiding dusfunction after polytetrafluoroethylene suburethral sling placement. Obstet Gynecol. 1996;87(1):50-4.

5. Beadnell SW, Connaughton B, Farhood VW. Management of postoperative urinary retention. J Oral Maxillofac Surg. 1989;47(12):1307-10.

6. Lukasse M, Cederkvist HR, Rosseland LA. Reliability of an automatic ultrasound system for detecting postpartum urinary retention after vaginal birth. Acta Obstet Gynecol Scand. 2007;86(10):1251-5.

7. Darrah DM, Griebling TL, Silverstein JH. Postoperative urinary retention. Anesthesiol Clin. 2009;27(3):465-84.

8. Dobbs SP, Jackson SR, Wilson AM, Maplethorpe RP, Hammond RH. A prospective, randomized trial comparing continuous bladder drainage with catheterization at abdominal hysterectomy. Brit J Urol. 1997;80(4):554-6. 
9. Hakvoort RA, Elberink R, Vollebregt A, Ploeg T, Emanuel $\mathrm{MH}$. How long should urinary bladder catheterisation be continued after vaginal prolapse surgery? A randomised controlled trial comparing short term versus long term catheterisation after vaginal prolapse surgery. BJOG. 2004;111(8):828-30.

10. Tammela T, Kontturi M, Käär K, Lukkarinen O. Intravesical prostaglandin $\mathrm{F} 2$ for promoting bladder emptying after surgery for female stress incontinence. Brit J Urol. 1987;60(1):43-6.

11. Petros JG, Rimm EB, Robillard RJ, Argy O. Factors influencing postoperative urinary retention in patients undergoing elective inguinal herniorrhaphy. Am J Surg. 1991;161(4):431-3.

12. Weemhoff M, Wassen M, Korsten L, Serroyen J, Kampschöer P, Roumen F. Postoperative catheterization after anterior colporrhaphy: 2 versus 5 days. A multicentre randomized controlled trial. Int Urogynecol J. 2011;22(4):477-83.

13. Glavind K, Mørup L, Madsen H, Glavind J. A prospective, randomised, controlled trial comparing 3 hour and 24 hour postoperative removal of bladder catheter and vaginal pack following vaginal prolapse surgery. Acta Obstet Gynecol Scand. 2007;86(9):1122-5.

14. Chai J, Pun TC. A prospective randomized trial to compare immediate and 24-hour delayed catheter removal following total abdominal hysterectomy. Acta Obstet Gynecol Scand. 2011;90(5):478-82.
15. Phipps, S, Lim YM, McClinton S, Barry C, Rane A, N'Dow JMO. Short term urinary catheter policies following urogenital surgery in adults. Cochrane Database of Syst Rev. 2006;2:CD004374.

16. Alessandri F, Mistrangelo E, Lijoi D, Ferrero S, Ragni N. A prospective, randomized trial comparing immediate versus delayed catheter removal following hysterectomy. Acta Obstet Gynecol Scand. 2006;85(6):716-20.

17. Niël-Weise BS, van den Broek PJ. Urinary catheter policies for short-term bladder drainage in adults. Cochrane Database Syst Rev. 2005;3:CD004203.

18. Makela M, Witt K. How to read a paper: critical appraisal of studies for application in healthcare. Singapore Med J. 2005;46(3):108-14.

19. Abdullah M, Firmansyah MA. Critical appraisal on journal of clinical trials. Acta Med Indones. 2012;44(4):337-43.

20. Sekhavat L, Farajkhoda T, Davar R. The effect of early removal of indwelling urinary catheter on postoperative urinary complications in anterior colporrhaphy surgery. Aust N Z J Obstet Gynaecol. 2008;48(3):348-52.

21. Dunn TS, Shlay J, Forshner D.Are in-dwelling catheters necessary for 24 hours after hysterectomy? Am J Obstet Gynecol. 2003;189(2):435-7.

22. Griffiths R, Fernandez R. Strategies for the removal of short-term indwelling urethral catheters in adults. Cochrane Database Syst Rev. 2007;(2):CD004011. 